た.

55 ：トルエン特よびキシレン暴露による脳内局所での 神経伝達物質の変化がいくつか見いだされているが，こ れらは合成系，分解系，局所間の移蕀状態などの，ぞの よらな変化にもとづくのか，知見がある゙ばとの橋本（金 沢大）の質問に対し，変動のメカニズムについてはこれ から検討するとの返答があった。

56 : 本間 (産医研) は末梢神経の形態学的変化につい てたずねたが，今後特こなら旨の答が苛った，小野（名 大）は 2,4-ペンタンジオンによる神経症状と 2,5-ヘキ サジオンのそれとの相違をたずねた。前者では前肢も障 害されると答えられた。四肢脱力以心筋や中枢神経の障 害が関与していないのか炕ついての鬼頭（名大）の問に 対して，不明で岕ると答えられた。

57 ：腎の肥大の理由と組織変化についての佐藤（信州 大）の問效して，不明であると答えられた，雇藤（信 州犬）は自分もいくつかの溶剂で $1,000 \mathrm{ppm}$ 程度の高 濃度になると腎肥大が起こりやすいことを経験している と述べた。

58 : 薬物代謝酯弯儿対する毒物の影響が，投与経路の 違いによって差が出ると言われているが，MCではどう かとの繀方（岡山大）の質問に対し，詳しく調べていな

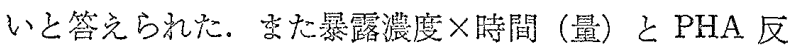
㐫との間相関が見られないかとの問い《詨して, PHA 反応怯対照群でも時によって変影し量の違いに上る相互 比較がすずかしいと答党られて。

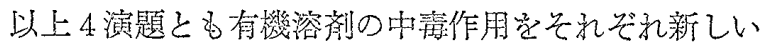
角度から追求するきわわて與味深い研究で，いずれも今 後の登展が期待される。

59. -Hexane の dose-effect relationship 小野雄一郎，竹内康浩，久永直見 (名大医衛生)

演者ら証すで数段階の滥度の $n$-hexane 江関して暴

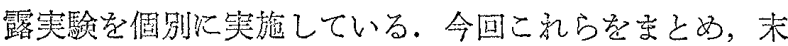
梢神経の霬気生理学的反応を指標として，n-hexane の 生体火対与る量一影響関係学検討した。動物生生後 11 週， 体重 $311 \pm 17 \mathrm{~g}(m \pm \mathrm{SD})$ の雄性ラット70匹を用いた。 $n$-hexane 暴露群として $3,000 \mathrm{ppm}$ 群 7 匹， $1,000 \mathrm{ppm}$ 群，500 ppm 群， $200 \mathrm{ppm}$ 群， $100 \mathrm{ppm}$ 群は和の徏の 8 匹息周いた. 対照群は, $n$-hexane 3,000 ppm 群に詨 し 7 匹，500 ppm 群，200 ppm 群蔺群共通の対照群と して 8 匹，1，000 ppm 群，100 ppm 群の対照群として各 8 匹を用いた。暴露は 1 日 12 時間連日行ない，ガスク

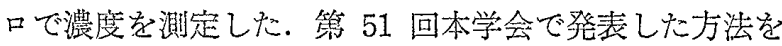

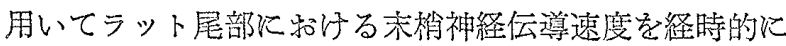

測定した。測定項目は MCV，MNCV，DL，ラット体重 とし，暴露開始直前拉よび暴露開始後 4 週ごとに測定を 行なった．その結果，対照群の值を常に100すると，暴 露群では体重, 末梢神経伀導速度が経時的飞㴬減 乙, distal latency が潮增する傾向を示した。尔た瀑度が高 い添ど傾向線の勾配が急になる傾向を示した. $n$-hexane の累䅡暴露量（濃度 $\times$ 時間）の璔加伴い，各䧳の各生

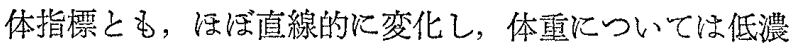

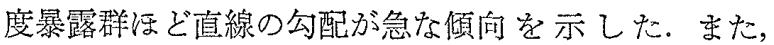
MCV, MNCV, DL については 3,000 ppm 群比し, $200 \sim 1,000 \mathrm{ppm}$ の各群で勾配が急な傾向学した。 MNCV については12 16週の間で，1,000，3,000 ppm 群でとくに低下する傾向を示した。 $200 \mathrm{ppm}$ 群の 20 週 以降， $500 \mathrm{ppm}$ 群 8 12 週以降儿比較的安定した有意 差が効照群との間飞得られ，また，3,000 ppm 群 10 週 からラットに歩行異常等の下肢症状が出現したので，対 照群との間に有意差の出始めるレベルとして，3 5X $10^{5} \mathrm{ppm} \times \mathrm{hr}$ ，外見的な末梢神経買常症状の出現与る ベルとして， $25 \times 10^{5} \mathrm{ppm} \times \mathrm{hr}$ が推定された.

\section{0. $n$-ヘキサンおよび石油ベンジンの神経㱟䍀に関す} る組織形態学的研究

鬼頭純三，杉浦厡夫（名大医解剖） 小野雄一郎，久永直見，竹内康浩

（名大医衛生）

小野らは第 53 回産業衛生学会飞和いて，nーヘキサン 特よび石油ベンジンの低濃度暴露々行ない, 20 週以上の 暴露で，体重增加の抑制，㖶動神経 ( $\mathrm{MCV})$ ，淈合神経 伝導速度 (MNCV) の低下，遠位部潜時（DL）の延長 が起こることを報告した，今回報告した成績はこのとき

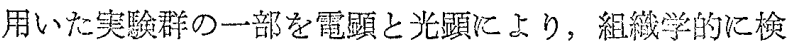
甞した所見である。

用いたシットは，24 週間暴露の各碓から, 生理学的測 定檤の平均值汇近い個体を選えだ，雪蹎用パラホルム。 グルタルアルデヒド混合固定液により心臟から㳊流固定 後, 組織片を切り出し, オスミック酸固定後, 未梢神経 の一部はグリセリン中で “とき漂ぐし標本”として光顕 的に観察した。他の組織は，型のごとく包畦し超薄切片 を作製し電顕的に観察した。

（1）布梢神経では全暴露群に，paranodal 方るいは

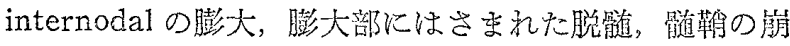
壊等が観察された。

（2）下腿筋で $n$-ヘキサン $500 \mathrm{ppm}$, 石油ベンジン（含 有ヘキサン賑度で） $500 \mathrm{ppm}$ 両群に，筋原線維の減少， 筋小胞体の膨化，筋原線維の走行と配列の乱就， $z$ 带の 流れ，榉紋の乱れない乙消失等がみられた，先れぞれの 
$200 \mathrm{ppm}$ 群では，変化は軽微であった。

（3）神経筋接合部では，多量の神経細線維が蓄積して 膨化した運動神経終末が石油ベンジン $200 \mathrm{ppm}$ 群で観 察されたが、その筇の筋原線維に乱れはみられなかった。

(4) 延噵薄束核には Spencer ら ('77) が giant axonal swelling として記載したような神経終末の膨大が みられ，内部には神経細線維のほか，特異な管状構造の 網工, myelin figures, multivesicular bodies 等がみら 孔た。

（5）行動等の観察では全群で歩行障害, 尖足, 筋菱縮 等は見られなかった。

座長のむと的 $(59 \sim 60)$

大森 蒵（横市大医衛生）

両演題は，演者らが数年来行なっている $n$-hexane 飞 関する一連の末梢神経の電気生理学的な検討から, 量・ 影響関係を求めよらとするるの拉よび組織形態学的な検 討の報告で岕った。

59 ：量・影響関係についての座長の質間に対し，竹内

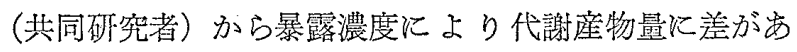

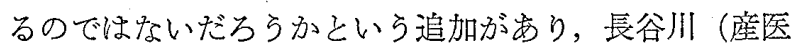
研）は代謝劣考学る上で暴露濃度の設定は慎重に考慮す べきとの指摘がなされ，緒方（岡山大）, 三角（熊本大） からる関連する意自が出された。

60 : 組織形態学的検索化当り, 三㞣（熊本大）から対 照群の取り扱い方, 池田（東北大）から標本検素の方法 等につき質問が满り，動物の飼育法抒よび標本作成時の 注意, 加齡変化に留意する必要のあることが示された。 また，標本恰索に関する有意義な討諭がなされた，両演 題とる討諭は活発であった。

61. テトラヒドロフランの吸入暴露察験 $(そ の 1)$ 血 液むよび骨に対する影響

片平卓男, 寺本敬子, 堀口俊一 (阪市大医衛生)

テトラヒドロフラン（以下 THF と略す）はビニル 樹脂に対する溶解能が大きく，扣もにとの溶凨として使 用されている有機溶剂で岁るが，揮発性が高いため，こ れを使用主る職塨に执いて，とくに吸大暴露に上る中毒

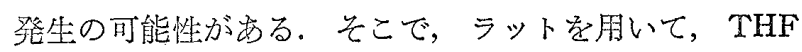
の長期吸入暴露实験を行ない，その生体への影響を観察 した，暴露方法は，ラット（雄，33四）を，対照群，低

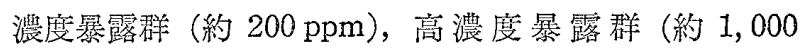
ppm）各 11 匹の 3 群汸汓て，1日4時間，1週 5 日 間，12週間飞方沉って暴露した。暴露終了日の 2 日 後, 剖检を行なって, 血液, 臟器叔よび, 骨を採取し, 以下の検查学行なった。血液検查（全血比重，血色素
量, ヘマトクリット, 赤血球数, 白血球数), 血清学的 検查 (GOT, GPT, アルカリフォスファターゼ, コリン エステラーゼ，総蛋白，コレステロール，トリグリセラ イド, 総ビリルビン, ZTT, TTT, AG 比, 血糖值), 組 織学的検查 (心, 肺, 脾, 婜, 膵，脳のーマトキシリン エオジン染色標本染作製し，光顕仙よる検鏡），X線検 查 (両側大腿骨頭のX線撮影), 体重測定（毎日），以上 の検查を行なった結果，度膚粘膜に対する刺激作用を認 めた以外は，すべての検查に括いて，対照群と暴露群と の間に，有意差を認めなかった，今回の実験恰，日本産 策衛生学会による THF の許容濃度で方る $200 \mathrm{ppm}$ と その 5 倍の濃度の $1,000 \mathrm{ppm}$ で暴露を行なったが，雨 暴露群ともに対照群との間に有意羑を認めなかった。少 なくとも許容濃度内で经，THF の毒性々強くないと思 わ就た。

62. テトラヒドロフランの吸入暴露寒験（その2）気

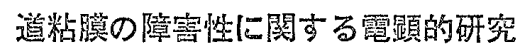

大祜淑宏，中并義明 (阪节大医耳鼻咽堠) 片平卓男, 寺本敬子, 堀口俊一

(阪市大医衛生公衛)

テトラヒドロフランは有機溶剤中毒予防規則の改正に より第 2 種有機溶剤伯加されている。テトラヒドロフ ランは化学工業に叔いて多く使用されているが，そ礼学 とり扱っている作業員の気道粘膜への影響も無視できな いと思わ礼る。しかし，これまでにテトラヒドロフラン の気道粘膜への影響について報告されたことがなかった ように思われるので，われわれはラットを用いて暴露実 験索行なった。

实験には SD 系雄性ラットを用いて，これら勳物を空 気の多を暴露した対照群, 約 $200 \mathrm{ppm}$ のテトラヒドロ

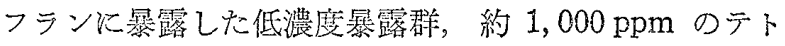
ラヒドロフランに暴露した高濃度暴露群の 3 群に分け て，それぞれ 12 週龄から 24 週跉までの 12 週間の暴露 学行なった。このようにして得られた動物を最終暴露翌 日に断䫟し，気管粘膜上皮々泉中隔粘膜上皮を走查なら びに透過電子顕微鏡究用いて钼察した。

低莀度暴露群では，1）絨毛細胞，杯細胞，基底細胞 なぞに種々の電子密度を有する高電子密度顆粒の出現,

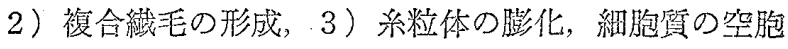

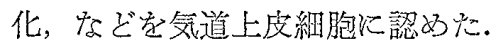

高濃度暴露群の気管上皮で最も目につく変化は繊毛の

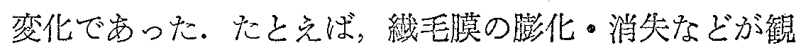
察され，なかでる複合絨毛の汧成が著明であった。 また 内部構造に乱れの方る複合瀻毛もかなり認められたが，

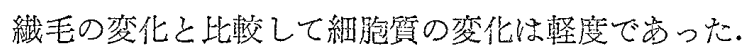

